\title{
WHO Global Strategy in Eradication of Cervical Cancer
}

\section{Patiyus Agustiansyah ${ }^{1,2^{*}}$, Rizal Sanif ${ }^{1}$, Siti Nurmaini ${ }^{3}$, Irfannuddin $^{4}$, Legiran $^{5}$}

${ }^{1}$ Department of Obstetric and Gynecology, Division Oncology of Gynecology, Faculty of Medicine, Universitas Sriwijaya / General Hospital Dr Moh. Hoesin, Palembang, Indonesia

${ }^{2}$ Doctoral Student, Biomedical Program, Faculty of Medicine, Universitas Sriwijaya, Palembang, Indonesia

${ }^{3}$ Intelligent System Research Group, Universitas Sriwijaya, Palembang, Indonesia

${ }^{4}$ Department of Physiology, Faculty of Medicine, Universitas Sriwijaya, Palembang, Indonesia

${ }^{5}$ Department of Anatomy, Faculty of Medicine, Universitas Sriwijaya, Palembang, Indonesia

\section{A R T I C L E I N F O \\ Keywords: \\ Cervical Cancer \\ Eradicated \\ Strategy}

*Corresponding author:

Patiyus Agustiansyah

\section{E-mail address:}

\section{fatiyusagustiansyah@gmail.com}

All authors have reviewed and approved the final version of the manuscript.

\begin{abstract}
A B S T R A C T
WHO has created a global strategy to accelerate the elimination of cervical cancer as a public health problem and a world burden. Cervical cancer is a disease that can be prevented and cured, as long as it is detected early and treated effectively. Cervical cancer is also a disease that reflects global injustice. The burden is greatest in low- and middle-income countries, where access to public health services is limited and screening and treatment for the disease has not been widely applied. In 2018, nearly $90 \%$ of all deaths worldwide occurred in low and middle income countries. Furthermore, the proportion of women with cervical cancer who die from the disease is more than $60 \%$ in these countries, more than double the number in many high-income countries, which is only $30 \%$.
\end{abstract}

https://doi.org/10.32539/bsm.v5i9.328

\section{Introduction}

WHO has created a global strategy to accelerate the elimination of cervical cancer as a public health problem and a world burden. Cervical cancer is a disease that can be prevented and cured, as long as it is detected early and treated effectively. Cervical cancer is also a disease that reflects global injustice. The burden is greatest in low- and middle-income countries, where access to public health services is limited and screening and treatment for the disease has not been widely applied. In 2018, nearly $90 \%$ of all deaths worldwide occurred in low and middle income countries. Furthermore, the proportion of women with cervical cancer who die from the disease is more than
$60 \%$ in these countries, more than double the number in many high-income countries, which is only $30 \% .1-10$

The human papillomavirus (HPV) is the leading cause of cervical cancer, and the HPV vaccine is a safe and effective way to protect women from HPV infection. But by 2020, less than a quarter of low-income countries have included the HPV vaccine in their national immunization schedules, while more than $85 \%$ of high-income countries have. Similar differences have been seen in the establishment of cervical cancer screening programs. "Most of these women are not diagnosed early enough, and do not have access to lifesaving care," said Dr Tedros Adhanom Ghebreyesus, WHO Director General, when he issued the Call for 
Action in 2018. "These women raise children, care for their families and contribute to the social and economic fabric of their communities. If we don't act, cervical cancer deaths will increase by almost $50 \%$ by 2040 . "With WHO's adoption of an elimination strategy, Dr Princess Nothemba Simelela, WHO Assistant DirectorGeneral for Strategic Priorities Programs, said the resolution provides an opportunity for leaders and supporters "to end injustice and restore the dignity of women."

To eliminate cervical cancer, all countries must achieve and maintain an incidence rate of under four per 100.000 women. Achieving this goal requires strategic action, and WHO outlines the actions needed in its global strategy, WHO's vision is for a world where cervical cancer is eliminated as a public health problem and safeguards the agenda by 2030.11-20

\section{Cervical cancer elimination strategy}

The WHO elimination strategy rests on three main pillars:

1. Primary prevention through vaccination

2. Screening and treatment of precancerous lesions

3. Treatment and palliative care for invasive cervical cancer

The three pillars must be implemented collectively and on a large scale to achieve the goal of elimination. HPV vaccination offers long-term protection against cervical cancer. Screening and treatment of precancerous lesions can prevent precancerous progression to cancer. For those identified with invasive cancer, timely care and treatment saves lives, while palliative care can greatly reduce pain and suffering.

Based on the three main pillars of the global strategy, WHO recommends a set of targets or milestones that every country must meet by 2030 to be on the path of eradicating cervical cancer within a century:

a. 90\% of girls are fully vaccinated with the HPV vaccine by age 15 ;

b. $70 \%$ of women screened using high performance tests at age 35, and again at age 45, (IVA screening coverage in Indonesia is only $7.3 \%$ as seen in figure
2.2) 27; and

c. $90 \%$ of women identified with cervical disease receive treatment $(90 \%$ of women with pre-treated cancer and $90 \%$ of women with managed invasive cancer).

Projections show that achieving the 90-70-90 target by 2030 could reduce the average cervical cancer incidence rate by $10 \%$ by 2030 , and by 2120,70 million cases could be prevented. In addition, an estimated 62 million cervical cancer deaths could be prevented by 2120. Meanwhile, implementing such strategies would save lives today. Strong monitoring systems, including population-based cancer registries, are essential for tracking progress and for making corrections to ongoing programs. Cervical cancer elimination will also provide positive economic and social outcomes. By 2030, approximately 250.000 women will remain members of the productive workforce, adding an estimated US \$ 28 billion to the world economy: US \$ 700 million as a direct result of increased labor force participation and an estimated US \$ 27 billion as indirect health benefits the good one. Cervical cancer elimination strategies in countries with limited resources are different from developed countries that have high resources. In high-resource countries, current screening strategies include cytology (microscopic evaluation), human papillomavirus (HPV) (DNA or RNA genotyping) or a combination of cytology and HPV DNA (co-testing). HPV testing is increasingly accepted because of its good negative predictive value (NPV). Co-testing provides slightly greater assurance in assessing cancer progression than simply carrying out an HPV test but incurs a greater cost; co-testing is primarily used in the United States. The triage option for determining whether or not a colposcopy (cervical examination) is required is debatable, and includes whether or not to perform an HPV type and cytology examination. Colposcopy biopsy remains the standard diagnostic to guide treatment, which often relies on the operative excision of precancerous lesions to provide a decision based on histopathologic results. In contrast, in low-resource countries, cytology, colposcopy, and 
histopathology services are limited. This is due to limited trained service resources, laboratory provision, limited laboratory infrastructure, limited testing due to socio-cultural problems and program continuity. ${ }^{7}$ Visual examination with acetic acid (IVA) is followed by ablative action (screen and treat program for women with screening positive is an inaccurate strategy.Lowcost HPV testing, if fully developed, will provide more accurate screening if resources are available; however, affordable and effective triage options and diagnostic tests, and treatment modalities, in developing countries are still unstable. The greatest opportunity to expand and improve cervical screening may be in middle-income countries that do not have an effective national program. computer-assisted and oncoprotein detection E6 and E7.28

The strategies for countries with limited resources include: 28

\section{Vaccinations}

One-dose vaccine validation is ongoing to reduce transmission of high-risk strains of the human papillomavirus (HPV). If proven effective, even for 5-10 years, a single dose program can provide protection and break the chain of transmission and reduce the endemicity of HPV infection. Vaccination at the peak age of sexual transmission can reduce cervical cancer incidence faster than restriction in young girls. This approach would be better if the one-dose program proved to be effective.

\section{Early detection / screening}

Visual inspection with acetic acid (IVA) is widely applied and involves visualization of the cervical surface without, or only with, low magnification. Randomized clinical trials (RCTs) show that IVA screening can reduce cervical cancer mortality by $30 \%$, but systematic reviews have shown IVA testing has limited sensitivity and specificity as shown in table 2.1.29 Silkenan et al. Stated problems with IVA accuracy, in other studies. It is said that the IVA sensitivity rate ranges from $49-98 \%$ and the specificity number $75-91 \%$ which has the potential to cause overdiagnosis and overtreatment in the future. ${ }^{11}$

HPV examination has better performance than IVA and cytology examination. Low-cost HPV testing continues to be improved and may be implemented. Testing techniques have also been improved so that patients can carry out the examination independently. ${ }^{11}$ The sensitivity of the HPV test is higher than that of IVA, but in some low-resource countries it shows a high prevalence of HPV where more than $30 \%$ of women may test positive if a highrisk strain of HPV is tested.

\section{Management}

The simplest approach is to immediately treat all HPV positive women aged > 30 years (past the peak childbearing age) with an ablative procedure, even though this is considered excessive (screen and treat program). Limit to those who have the highest risk types of HPV and some form of low-cost triage may be required for HPV screening. Widespread management of ablative therapy may slightly increase sexual transmission of infections (including HIV) if recommendations for sexual abstinence after treatment are not followed. A relatively inexpensive lateral flow assay (analogous to the pregnancy test) has been developed to detect oncoprotein HPV E6 of the most important carcinogenic HPV types (HPV16, HPV18 and HPV45). A test designed to detect seven or eight types of high-risk HPV is being tested. Simple and portable ablative methods are now available, including 'cryopen' and 'cold coagulation', which rely on electricity using battery power. This method may be more feasible than gas-based cryotherapy. 


\begin{tabular}{llcccccc}
\hline Country & $\begin{array}{c}\text { Nationwide } \\
\text { screening }\end{array}$ & $\begin{array}{c}\text { Beginning } \\
\text { of the } \\
\text { national } \\
\text { screeing } \\
\text { program }\end{array}$ & $\begin{array}{c}\text { Primary } \\
\text { screening } \\
\text { method }\end{array}$ & $\begin{array}{c}\text { Targeted } \\
\text { age }\end{array}$ & Interval & Uptake rates & $\begin{array}{c}\text { Confirmatory } \\
\text { test }\end{array}$ \\
\hline China & Available & 2009 & $\begin{array}{c}\text { Cytology, } \\
\text { HPV test }\end{array}$ & $18-65$ & 3 years & $16.9 \%-29.1 \%$ & Colposcopy \\
\hline India & $\begin{array}{l}\text { Partially } \\
\text { available }\end{array}$ & 2007 & VIA & $30-59$ & 2 years & $5 \%$ & See and treat \\
Indonesia & Available & 2014 & $\begin{array}{l}\text { VIA, } \\
\text { Cytology }\end{array}$ & $30-50$ & $3-5$ years & $7.3 \%$ & See and treat \\
\hline Japan & Available & 1962 & Cytology & $>20$ & 2 years & $30 \%$ & Colposcopy \\
\hline Korea & Available & 1999 & Cytology & $>20$ & 2 years & $53.5 \%$ & Colposcopy \\
\hline $\begin{array}{l}\text { Thailand } \\
\text { HPV, human }\end{array}$ & Available & 2005 & Cytology & $35-65$ & 2 years & $46.3-59.7 \%$ & Colposcopy \\
\hline
\end{tabular}

Figure 1. National cervical cancer screening program in Asian countries, $2020^{27}$

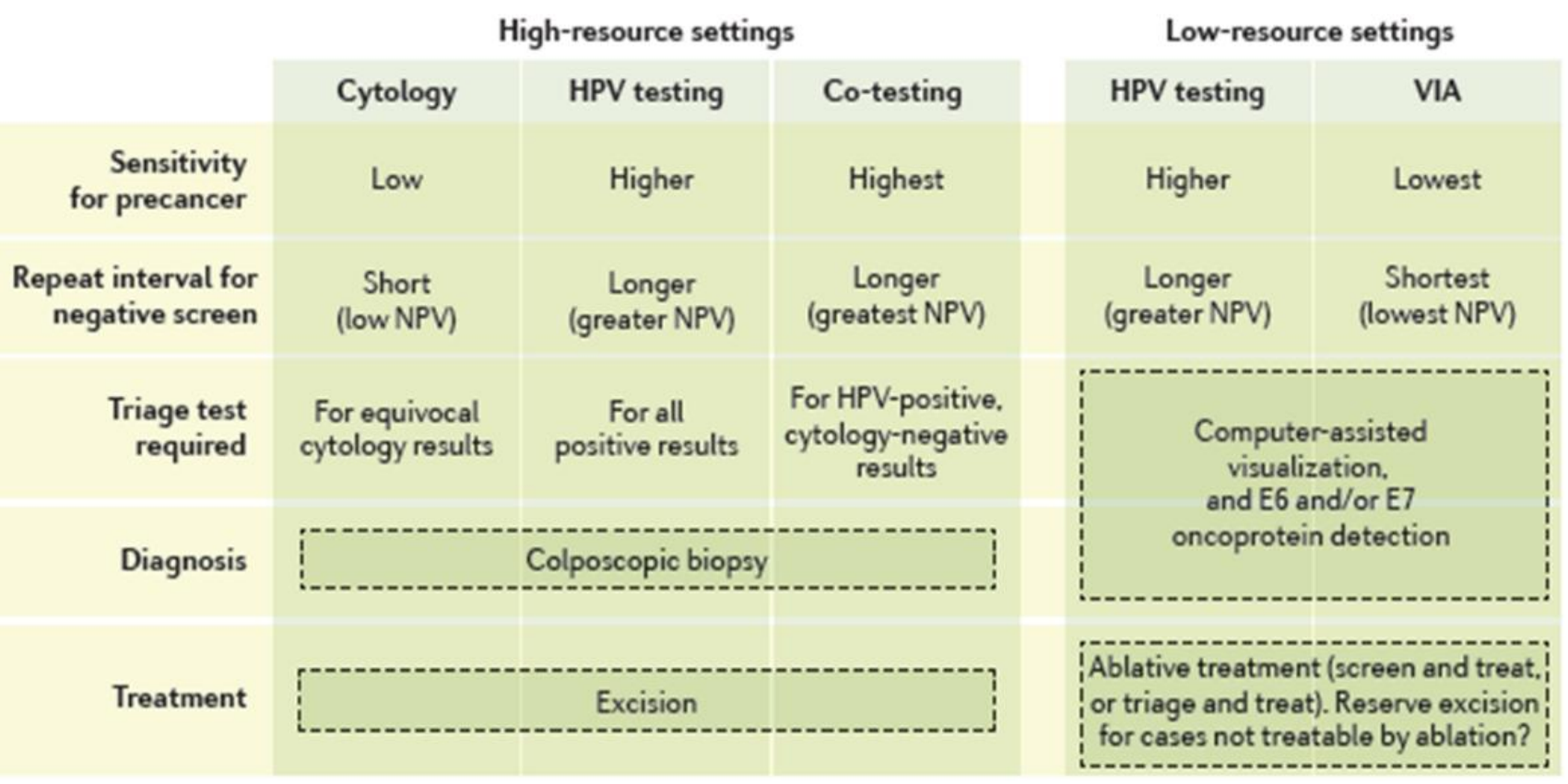

Figure 2. High- and low-resource country screening strategies 28 


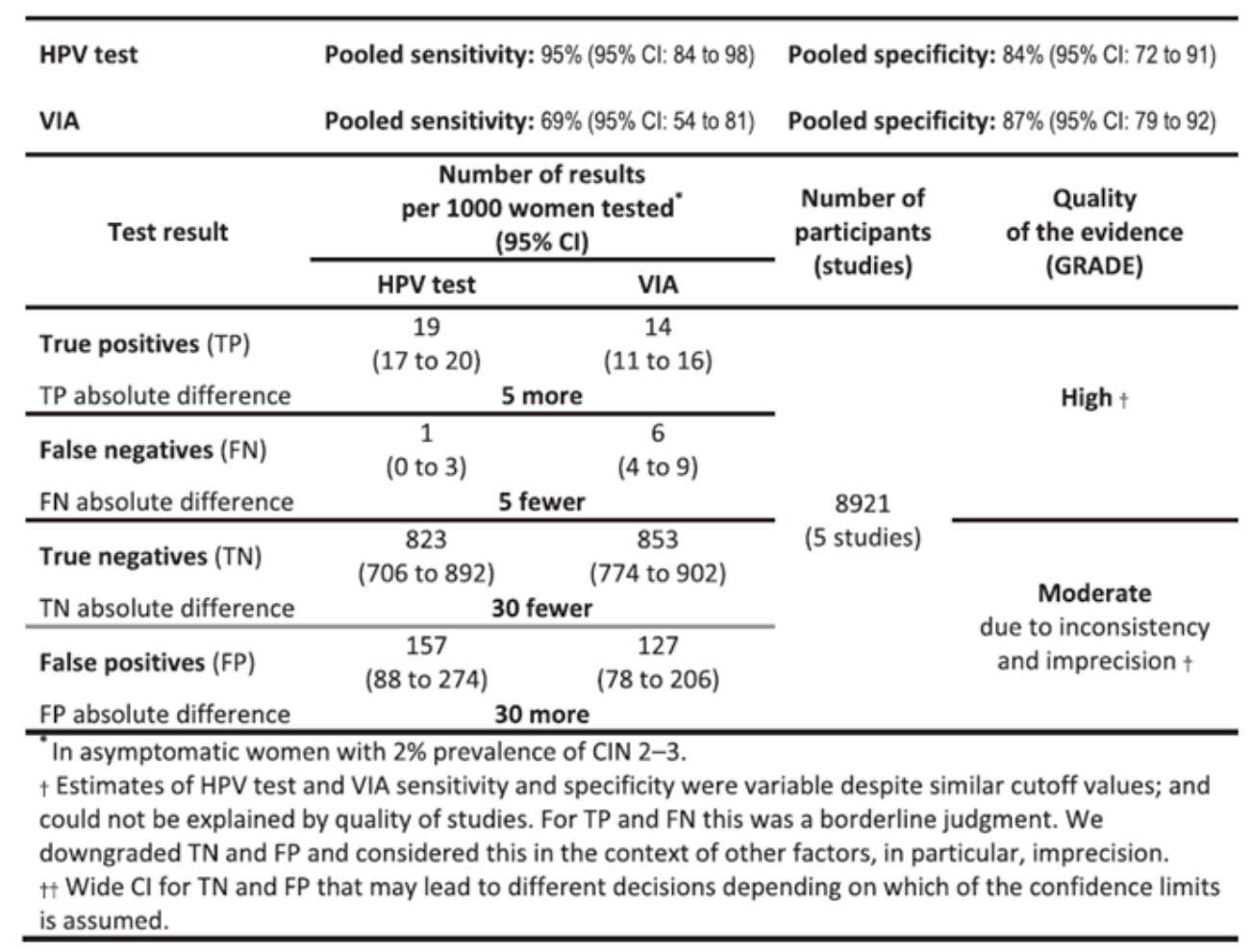

Figure 3. Comparison of the accuracy of the IVA screening examination with HPV DNA29

Decision-making flowchart for programme managers

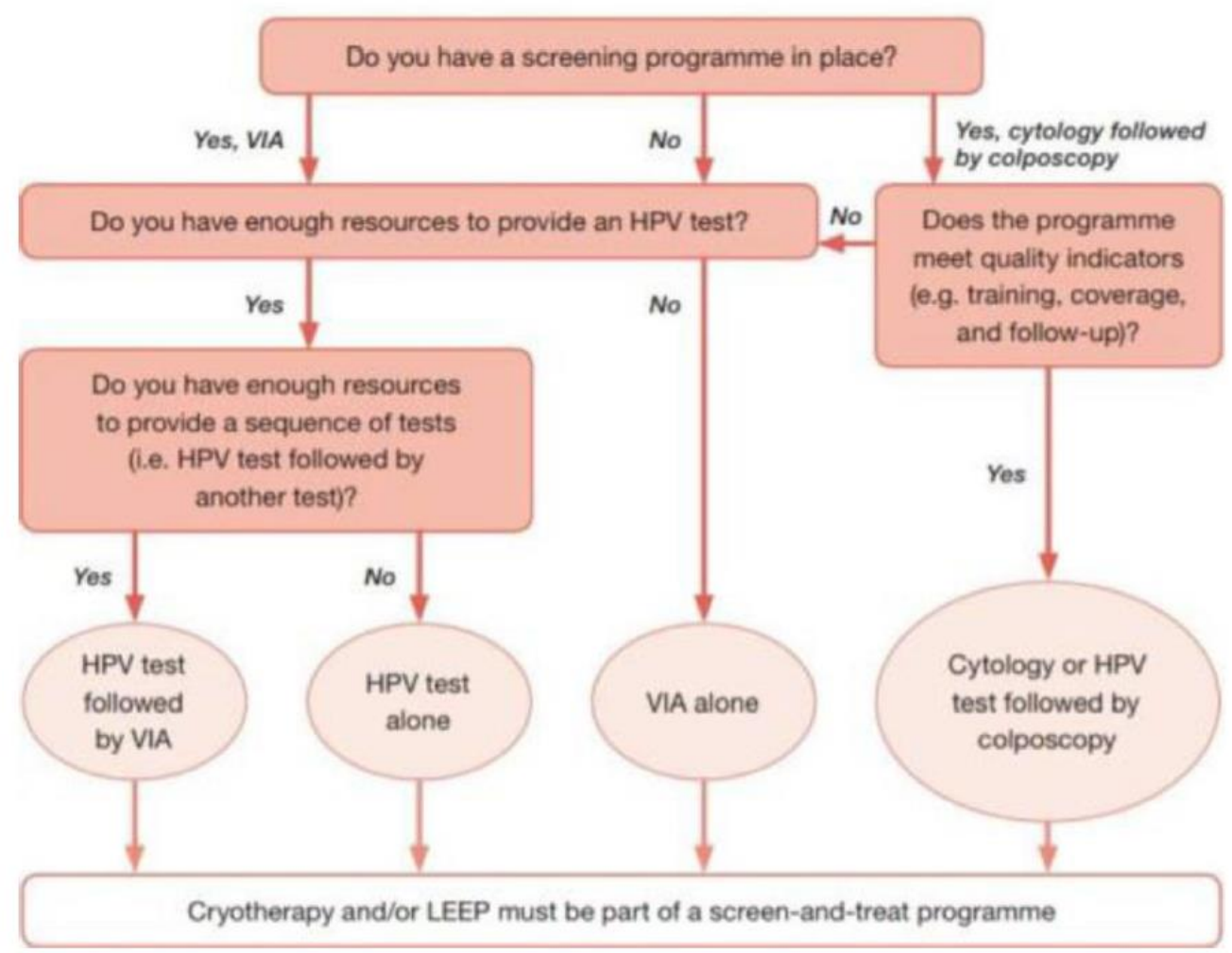

Figure 4. Algorithm for a screen and treat program in low resource countries 7 


\section{References}

1. Min KJ, Lee JK, So KA, Kim MK. Association Between Passive Smoking and the Risk of Cervical Intraepithelial Neoplasia 1 in Korean Women. $J$ Epidemiol. 2018;28(1):48-53. doi:10.2188/jea.JE20160118

2. WHO. WHO Global world health assembly adopts global strategy to accelerate cervical cancer elimination. Published 2020. Accessed October

29 , 2020. https://www.who.int/news/item/19-08-2020world-health-assembly-adopts-global-strategyto-accelerate-cervical-cancer-elimination

3. Aoki E, Yin R, Li K, et al. National screening programs for cervical cancer in Asian countries. J Gynecol Oncol. 2020;31(3). doi.org/10.3802/jgo.2020.31.e55

4. Schiffman M, Doorbar J, Wentzensen N, Monk BJ, Stanley MA, Franceschi S. Carcinogenic human papillomavirus infection. Nat Rev Dis Prim. 2016;2:1-20. doi:10.1038/nrdp.2016.86

5. Mustafa RA, Santesso N, Khatib R, et al. Systematic reviews and meta-analyses of the accuracy of HPV tests, visual inspection with acetic acid, cytology, and colposcopy. Int $J$ Gynecol Obstet. Published online 2015. doi:10.1016/j.ijgo.2015.07.024

6. Asiaf A, Ahmad ST, Mohammad SO, Zargar MA. Review of the current knowledge on the epidemiology, pathogenesis, and prevention of human papillomavirus infection. Eur $J$ Cancer Prev. 2014;23(3):206-224. doi:10.1097/CEJ.0b013e328364f273

7. Arkhangelskaya TA, Prokhorov M V., Mazirov MA. Annual temperature dynamics of arablesoils of Vladimir opolye paleocryogenic complexes. Earth's Cryosph. 2008;12(3):80-86.

8. Development C. Key Molecular Events in Cervical Cancer Development. Published online 2019.

9. Ibeanu OA. Molecular pathogenesis of cervical cancer. Cancer Biol Ther. 2011;11(3):295-306. doi:10.4161/cbt.11.3.14686

10. Murdiyarso LS, Kartawinata M, Jenie I, Widjajahakim G, Indonesia GÁ, Hpv ÁHHPVÁL. Single and multiple high-risk and low-risk Human Papillomavirus association with cervical lesions of 11,224 women in Jakarta. Cancer Causes Control. Published online 2016. doi: 10.1007/s10552-016-0816-4

11. Stark H, Živković A. HPV Vaccination: Prevention of Cervical Cancer in Serbia and in Europe. Acta Fac Medicae Naissensis. 2018;371(4):5-16. doi:10.2478/afmnai-20180001

12. Human P, Hpv P, Evriarti PR, Yasmon A. Metode yang disusun dengan pendekatan telusur menimbulkan kanker pada manusia . Papillomavirus bersama Poliomavirus masuk dalam family yang sama ). Famili Namun yang paling sering ditemukan pada pasien adaah genus Alphapapillomavirus.

13. Moscicki AB, Schiffman M, Burchell A, Albero G, A. R. Giuliano, M. T. Goodman SKK and JP. Updating the Natural History of Human Papillomavirus and Anogenital Cancers. Vaccine. 2013;30(Suppl 5):F24-F33. doi:10.1016/j.vaccine.2012.05.089.Updating

14. Bosch FX, Broker TR, Forman D, et al. Comprehensive Control of Human Papillomavirus Infections and Related Diseases ฐ. Vaccine. 2013;31:H1-H31. doi:10.1016/j.vaccine.2013.10.003

15. Bharti AC, Singh T, Bhat A, Pande D, Jadli M. Therapeutic startegies for human papillomavirus infection and associated cancers. Front Biosci Elit. 2018;10(4):15-73.

16. Cobo F. Human Papillomavirus Infections: From the Laboratory to Clinical Practice. 1st ed. (Publishing W, ed.). Elsevier Inc.; 2012.

17. Doorslaer K Van, Chen Z, Bernard H, et al. ICTV ICTV Virus Taxonomy Profile: Papillomaviridae. Published online 2018:989-990. doi:10.1099/jgv.0.001105 
18. Crosbie EJ, Einstein MH, Franceschi S, Kitchener HC. Human papillomavirus and cervical cancer. Lancet. 2013;382(9895):889899. doi:10.1016/S0140-6736(13)60022-7

19. Longworth MS, Laimins LA. Pathogenesis of Human Papillomaviruses in Differentiating Epithelia. 2004;68(2):362-372. doi:10.1128/MMBR.68.2.362

20. Role O, Techniques D. The Human Papillomavirus ( HPV) in Human Pathology: Description, The Human Papillomavirus ( HPV) in Human Pathology : Description, Pathogenesis , Oncogenic Role, Epidemiology and Detection Techniques. Open Dermatol J. 2009;3:90-102. doi:10.2174/1874372200903010090

21. Muñoz N, Bosch FX, De Sanjosé S, et al. Epidemiologic classification of human papillomavirus types associated with cervical cancer. $N$ Engl $J$ Med. 2003;348(6):518-527. doi:10.1056/NEJMoa021641

22. IARC IAFROC. Monographs on the Evaluation of Carcinogenic Risks to Humans Human Papillomaviruses.; 2007.

https://monographs.iarc.fr/wpcontent/uploads/2018/06/mono90.pdf

23. Hwang E, Nottoli T, DiMaio D. HPV 16 E5 protein: expression, detection and stable complex formation with transmembrane protein in COS cells. Virology. 1995;211:227-233.

24. Zhang B, Spandau DF, Roman A. E5 Protein of Human Papillomavirus Type 16 Protects Human Foreskin Keratinocytes from UV B-IrradiationInduced Apoptosis. 2002;76(1):220-231. doi:10.1128/JVI.76.1.220

25. Moody CA, Laimins LA. Human papillomavirus oncoproteins : pathways to transformation. Nat Publ Gr. 2010;10(8):550-560. doi: $10.1038 / \mathrm{nrc} 2886$

26. Spataro V, Norbury C, Harris AL. The ubiquitinproteasome pathway in cancer. $\mathrm{Br} J$ Cancer. 1998;77:448-455.

27. Bornstein $\mathrm{J}$, Lahat $\mathrm{N}, \mathrm{Ph} \mathrm{D}$, et al. Interferon- b and - g , but Not Tumor Necrosis Factor- a , Demonstrate Immunoregulatory Effects on Carcinoma Cell Lines Infected with Human Papillomavirus. Cancer. 1997;79:924-934.

28. Ghaderi M, Nikitina L, Peacock CS, et al. Tumor Necrosis Factor a-11 and DR15-DQ6 ( B * 0602 ) Haplotype Increase the Risk for Cervical Intraepithelial Neoplasia in Human Papillomavirus 16 Seropositive Women in. Cancer Epidemiol Biomarkers Prev. 2000;9(October):1067-1070. 